Arab Univ. J. Agric. Sci., Ain Shams Univ., Cairo, Egypt 29(2), 677-688, 2021

Website: http://ajs.journals.ekb.eg

DOI: 10.21608/ajs.2021.61285.1339

\title{
Physico-Chemical Properties, Fractionation and Antioxidant Activity of Some Essential Oils Utilized in Mayonnaise Preparation and Storage
}

\section{Mammdouh H EL-Kalyoubi ${ }^{1}$, Mohamed M Khalaf ${ }^{1}$, Abdel-Aziz N Shehata ${ }^{2}$, Wafaa M Abozeid ${ }^{2}$, Mohamed E Mansour ${ }^{2 *}$}

1- Food Sciences Dept, Faculty of Agriculture, Ain Shams University, P.O. Box 68, Hadayek Shoubra 11241, Cairo, Egypt

2- Food Sciences \& Tech Dept, National Research Centre, Cairo, Egypt

*Corresponding author: hamada.sro@gmail.com, ORCID (0000-0001-7553-3096) and stachys essential oils had an antioxidant activity similar to synthetic antioxidant of TBHQ at a concentration of $200 \mathrm{ppm}$ for inhibition of secondary oxidation products in mayonnaise in comparison with the control sample. As a conveniently available source of natural antioxidants, thyme and stachys essential oils can be used for use in fats, oils and food containing fats.

Keywords: Rancimat, Antioxidant, Stachys, Thyme, Essential oil, Mayonnaise.

\section{Introduction}

One of the main factors causing degradation is lipid oxidation through storage and producing oils, fat-containing products and edible fats. It alters fat and oils' main quality control parameters, such as colour, flavor, aroma, and nutritional value, affecting consumption suitability (Nogala-Kalucka et al 2005). Oils chemical structure makes them more vulnerable to oxidation because of the higher content of polyunsaturated fatty acids (PUFA). To address the fat and oil stability problem, synthetic antioxidants such as BHA and BHT are integrated with fats and oil (Choe and Min 2009). 
Consumers are today becoming more aware of their food and food additives throughout the world's nutritional value and safety. Natural food and food additives are preferred around the same time that is considered safer, cheaper and less toxic than artificial ones (Zugravu etal2017). However, the decrease in the usage of synthetic antioxidants in food products was attributed to their instability and their supposed position as promoters for carcinogenesis. As a result of these safety concerns, food scientists are increasingly replacing synthetic with natural antioxidants, which are usually expected to be safer (Yanishlieva and Marinova 2001). It is understood that adding specific aromatic spices or herbs to lipidcontaining materials has retarded the oxidation development for some time (Choe and Min 2009). Many medical herbs and spices have been declared to be more effective in retarding the lipid oxidation development in oils and fats with antioxidant properties (Yanishlieva and Marinova 2001, Nogala-Kalucka et al 2005, Choe and Min 2009, Roy et al 2010).

Based on complex toxicity studies, in foods for safety and approval at low concentrations, synthetic antioxidants were tested. Although in most countries synthetic antioxidants are commonly used, confusion remains concerning their safety (Shahidi 2005). Because of their potential toxic effects during long-term usage, the safety of synthetic antioxidants is still a controversial problem. If synthetic antioxidants are unlikely to be harmful, it seems fair to attempt to substitute them with natural antioxidants that are more compatible with human existence (Taghvaei and Jafari 2015).

Mayonnaise is an emulsion of oil-in-water. The emulsion comes from a slow blend of oil and pre-mixed egg yolk, vinegar and mustard as a water-in-oil emulsion is created by immediate addition of the oil and aqueous phase. It is one of the oldest and most used sauces in the world today (Depree and Savage 2001). One of the main causes of mayonnaise chemical spoilage is oxidation, leading to rancidity and/or degradation of nutritional quality, colour, taste, texture and food safety. In lipid-bearing foods, oxidation of lipids is a major problem, particularly in food products that have highly polyunsaturated fatty acids (PUFA). Unless careful steps are taken, lipid oxidation happens nearly immediately in the food containing these lipids. When highly unsaturated oils are emulsified in different food systems, specific problems arise (Frankel et al 2002). A growing interest in aromatic herbs, in both the industry and in science study due to their antimicrobial and antioxidant properties (Vahidyan et al 2012).

Essential oils are volatile plant components that cause plant aromas (Ali et al 2015). Mankind has been utilized in food, cosmetics and traditional healing medicines since ancient times. Throughout the food and medicine industry, these aroma components of plant oils are used as flavor enhancers and fragrances industry, etc. (Shrivastava et al 2010). Thyme is an evergreen shrub aromatic from the Lamiaceae family, also known in Arabic as Zaatar is a widespread species planted in the Arab world (Basch et al 2004). Several lab experimental studies have also shown that essential thyme oil has good antimicrobial and antioxidant properties (Boskabady et al 2006, Rota et al 2008, Grigore et al 2010). Thyme oil, throughout its aroma and commercial value is used in different types of nutrients and drinks. It is also used in the food industry as a natural food preservative (Bhavaniramya et al 2019).

Stachys herbal tea is used for the treatment of gastrointestinal and respiratory disorders in southern Anatolia. The hydrodistillation derivatives of stachys essential oil were also studied, by both of GC-FID and GC/MS techniques. Therehave been 37 known compounds made up of $98.3 \%$ of the essential oil. The main components of stachys oil are $\beta$-Phellandrene, $\alpha$-pinene and germacrene-D. $(27,18.5$ and $13 \%$, respectively). Antioxidant properties showed a surprisingly radical scavenging behavior (Iscan et al 2012). 
This study will open the way for thyme and stachys essential oils to classify the main volatile constituents and their antioxidant capabilities as natural antioxidants agents in mayonnaise stored at room temperature $\left(25^{\circ} \mathrm{C}\right)$ which can be used in the food industry.

\section{Materials and Methods}

\subsection{Materials}

Thyme "Thymus vulgaris L." leaves were purchase from the local market (haraz store, Cairo, Egypt), Stachys “Stachys aegyptiaca”" was collected from Bani Sweif governorate, Egypt. The leaves were air-dried at $40^{\circ} \mathrm{C}$ overnight until it is completely dry after detached from the branches and stored in a polyethylene bag at $4^{\circ} \mathrm{C}$. Free antioxidant sunflower oil was kindly supplied from ARMA $\left(10^{\text {th }}\right.$ of Ramadan city, Egypt). Butylated hydroxytoluene (BHT) was obtained from Merck (Darmstadt, Germany). Sugar, mustard flour, white pepper, eggs, lemon and salt were purchased from a local market, Giza, Egypt.

\subsection{Extraction of essential oils}

In Clevenger's apparatus, 3 hours hydrodistilled extraction process for the isolation of the essential oils from air-dried thyme and stachys were carried out. Anhydrous sodium sulphate was used for drying the essential oil then the resulted oil was stored in dark glass bottles before analysis and the extraction yield was measured (Yağci et al 2012).

\subsection{Preparation of mayonnaise}

The following ingredients were included in the Mayonnaise control sample (w/w): sunflower oil $70 \%$, egg yolk $22.17 \%$, vinegar $0.63 \%$, sugar $0.63 \%$, salt $1.26 \%$, mustard powder $0.31 \%$, white pepper 0.31 and lemon juice $2.20 \%$. Thyme, Stachys essential oils and TBHQ (control+) were individually used for the preparation of mayonnaise samples in the antioxidant-free oil of sunflower at concentrations of $200.400,600$ and $200 \mathrm{ppm}$ for each.
Egg yolk and other powdered materials were initially mixed for 30 s with water $2.49 \%$. In the aqueous process sunflower oil and vinegar have then been added, and the emulsion is then mixed for 1 minute. The mayonnaises were labelled after preparation and covered with screw caps in glass jars. These samples have been kept for 5 weeks at $25^{\circ} \mathrm{C}$ (Nadir et al 2003).

2.4 Physicochemical measurements of thyme and Stachys essential oils

2.4.1 Specific gravity (SP.gr): using a pycnometer $\left(10 \mathrm{~mL}\right.$ capacity) at $20^{\circ} \mathrm{C}$, the specific gravity of thyme and stachys essential oils was determined according to the reporting procedure by Parthiban et al (2011).

2.4.2 Refractiveindex (RI): The refractive index (RI) of thyme and Stachys essential oils was determined by using an Abbe Refractometer at $20^{\circ} \mathrm{C}$, by the method defined by Parthiban et al (2011).

2.4.3 Acid value (AV): Acid value (AV) of thyme and stachys essential oils as $\mathrm{mg}$ $\mathrm{KOH} / \mathrm{gm}$ oil was determined according to the methods outlined by Parthiban et al (2011).

\subsection{Identification of thyme and Stachys es- sential oil constituents by GC/MS technique}

The essential oils were analysed using the capillary column VF-5, MS $(30 \mathrm{mX} 0.25 \mathrm{~mm}$ ID and $0.25 \mu \mathrm{m}$ thickness film) and interfaced with the selective mass selective detectorGC/MS Model (Varian240-MS). A helium flow rate at $1 \mathrm{ml} / \mathrm{min}$ as the carrier gas. Direct injection $(1 \mu \mathrm{L})$ into the divided injector has analysed the essential oils of thyme and Stachys. The temperature of the injector and detector was $250^{\circ} \mathrm{C}$. The column oven was programmed to temperatures between 45 and $240^{\circ} \mathrm{C}$ at $45^{\circ} \mathrm{C} / 10$ and $6^{\circ} \mathrm{C} / 15 \mathrm{~min}$ at a rate of $240^{\circ} \mathrm{C}$. A range of mass-spectrums from $20-$ $425 \mathrm{amu}$ was acquired, with 0.5 scans per second. Thyme and Stachy's essential oils were identified in a comparison between the retention times and the authentic standards that 
were injected in the devices under the same conditions and their mass spectra were compared to those of the Wiley library. The quantitative measurement was based on the integrations of the peak area (Shrestha et al 2013).

\subsection{Radical scavenging activity using DPPH assay}

DPPH experiments with a $517 \mathrm{~nm}$ spectrophotometer have determined antioxidant activity. The potential to donate thyme and Stachys essential oils hydrogen atoms or electrons was calculated by bleaching DPPH solution to light-yellow (Goze et al 2009). Fifty microliters of various concentrations $(50,100,200$, $250,300,350,400,450$ and $500 \mu \mathrm{g} / \mathrm{mL}$ : "ppm") of the essential oil in methanol as well as BHT, as a standard antioxidant $(50,100$, 150 and $200 \mu \mathrm{g} / \mathrm{mL}$ ) were put into appropriate tubes, and $4 \mathrm{~mL}$ of $0.004 \%$ methanolic solution of DPPH was added to each tube and vigorously shaken (Gülçin 2006). The tubes should stand for 30 minutes at room temperature. Control without any sample was prepared simultaneously. For the preparation samples, absorption variations have been measured at $517 \mathrm{~nm}$. Radical scavenging activity was calculated by using the following formula as the $\%$ inhibition:

$$
\% \text { Inhibition }=\frac{\mathrm{AB}-\mathrm{AA}}{\mathrm{AB}} \times 100 .
$$

Where: AB: absorption of blank sample $(\mathrm{t}=0$ $\min ), A A$ : absorption of sample solution ( $\mathrm{t}=30$ $\min )$.

\subsection{Measurement of oxidative stability of sunflower oil}

Rancimat test was used to determine the antioxidant activity of thyme and stachys essential oil added at levels of 200 and 500 ppm which were mixed well with sunflower oil using magnetic stirrer, in comparison to BHT (200 ppm), and pure sunflower oil (without any addition, as a control).
Sunflower oil oxidative stability with and without the addition of antioxidant was determined under accelerated conditions $\left(100^{\circ} \mathrm{C}\right.$, Oxygen flow at 20L/hr.) using Rancimat 743 (Metrohm, Switzerland), the induction period (IP) was conducted with Rancimat (Anwar et al 2003).

The antioxidant activity (AA) and increasing index $\%$ were calculated from the measured induction times according to Holasova et al (2006), as follows:

Antioxidant activity $(\mathrm{AA})=\frac{\text { Ind. time of oil with antioxidant }}{\text { Ind. time of control }}$

Increasing Index $\%=\frac{\text { IP with antioxidant }-\mathrm{IP} \text { of the control }}{\mathrm{IP} \text { of the control }} \mathrm{X} 100$.

2.8 Measurement of acid value (AV) of mayonnaise

The acid value (AV) of mayonnaise samples were performed according to AOCS (2005).

\subsection{Thiobarbituric acid value (TBA) of may- onnaise}

Thiobarbituric acid value (TBA) of mayonnaise were performed according to AOCS (2005).

\subsection{Statistical Analysis}

Statistical analyses were conducted by SPSS V.15.0 program. Data on chemical, oxidation and microbiological evaluations were carried out by ANOVA (Benjakul et al 2003).

\section{Results and Discussion}

\subsection{Yield percentage and physicochemical properties of thyme and stachys essential oils}

In this research, two essential oils (thyme and Stachys) were tested as antioxidant agents, their physicochemical being defined first. 
The percentage of thyme and stachys essential oils yield was determined and the obtained results are presented in Table 1. The present findings showed that the average yield of thyme and stachys essential oils obtained from the three-hour hydrodistillation of shadedried thyme and stachys leaves was 0.92 and $1.5 \%(\mathrm{v} / \mathrm{w})$, respectively, implying that, from an economic point of view, dried thyme and stachys leaves were good sources of highly valuable essential oils. Results were consistent with Gedikoğlu et al (2019).

To get closer to the consistency and purity of essential oils, physicochemical properties such as specific gravity, refractive index and acidity are very useful. These criteria are critical for the production of quality essential oil that will help to improve the community as well as the nation's economic condition (Boukhatem et al 2014). The physicochemical properties of thyme and stachys essential oils have been assessed and the obtained findings are presented in Table 1. Results in Table 1 revealed that specific gravity of thyme and stachys essential oils at $20^{\circ} \mathrm{C}$ was 0.912 and $0.9782 \mathrm{gm} / \mathrm{cm}^{3}$, respectively, which indicates high quality and purity of the volatile oil. In this concept, it should be mentioned that the specific gravity value for thyme and stachys essential oils is less than $1 \mathrm{gm} / \mathrm{cm}^{3}$ (Guenther, 1961). The refractive index of thyme and stachys essential oils as shown in Table 1 was 1.4680 and 1.4125 , respectively. The refractive index of pure oil depends on the molecular weight of the compounds within the volatile oil. Results are in agreement with those obtained by Constantin et al (2014), Shaheen et al (2017). Thyme and stachys essential oils obtained were yellow-brown and Colorless, respectively Results are in agreement with those obtained by Constantin et al (2014), Shaheen et al (2017). Data demonstrated in Table 1 cleared that the acid value of thyme and stachys essential oils was 2.52 and $3.18 \mathrm{mg}$ $\mathrm{KOH} / \mathrm{gm}$ oil, respectively. The acid value is an important criterion of the freshness, quality and purity of the essential oil, most essential oils contain only a small amount of acid $v$ alues (Kumar, 2014).
Table 1. Physio-chemical properties of thyme and Stachys essential oils

\begin{tabular}{|l|c|c|}
\hline Characteristic & Thyme & Stachys \\
\hline Appearance & transprent fluid & $\begin{array}{c}\text { transprent } \\
\text { fluid }\end{array}$ \\
\hline Colour & yellow-brown & Colorless \\
\hline Odor & thyme & menthol \\
\hline $\begin{array}{l}\text { Relative density, } \\
\text { g/ } \mathrm{cm}^{3}\end{array}$ & 0.912 & 0.9782 \\
\hline $\begin{array}{l}\text { Refractive index } \\
\left(20^{\circ} \mathrm{C}\right)\end{array}$ & 1.4860 & 1.4125 \\
\hline $\begin{array}{l}\text { Acid value, } \\
\mathrm{mg} \mathrm{KOH/g}\end{array}$ & 2.52 & 3.18 \\
\hline Yield\% & 0.92 & 1.5 \\
\hline
\end{tabular}

\subsection{Identification of the chemical constitu- ents of thyme and Stachys essential oils}

Using gas chromatography coupled with mass spectrometry (GC/MS) technique, thyme 'Thymus vulgaris L.' and stachys 'Stachys aegyptiaca' essential oils obtained by hydro-distillation were fractionated and classified. The chemical components were calculated based on retention time and compared with the standard compound mass spectral database and their relative proportions (area\%) are shown in Table 2.

It was evident from the results of Table 2 that thyme had 15 components, representing $99.99 \%$ of the total essential oil, while unknown components represented $0.01 \%$ of the total oil. Stachys oil, however, has 33 components that represent $99.22 \%$, while unknown components represent $0.78 \%$. GC/MS analysis (Table 2) indicated that the major components in thyme essential oil were thymol (62.28\%) and in stachys essential oil were $\beta$-elemenone and Isojasmone (33.63 and $31.57 \%$, respectively). These results were consistent within the ranges of thyme and stachys essential oils published by Shaheen et al (2017), Alsaraf et al (2020).

Due to their antioxidant activity, phenolic compounds such as thymol in essential thyme oil plays an important role (Braga 2005). Similar classification groups were observed for both thyme and stachys essential oils with small variations in component concentrations 
Table 2. Fractionation of thymus \& stachys essentialoils using GC- MS

\begin{tabular}{|c|c|c|c|}
\hline \multirow{2}{*}{$\mathbf{R}_{\mathbf{t}}$} & \multirow{2}{*}{ Compound Name } & \multicolumn{2}{|c|}{ Area \% } \\
\hline & & Stachys & thyme \\
\hline 3.19 & p-cymeme & N.D. & 6.28 \\
\hline 3.29 & Eucalyptol & 3.13 & N.D. \\
\hline 4.59 & $\alpha$ - linalool & N.D. & 6.83 \\
\hline 4.93 & 3-octanol-acetate & 0.45 & N.D. \\
\hline 5.16 & Imidazole & 0.15 & N.D. \\
\hline 5.52 & (1)-isomenthone & 0.42 & N.D. \\
\hline 5.79 & p-menthan-3-one & 3.12 & N.D. \\
\hline 6.01 & Cis-iso pulegone & 1.1 & N.D. \\
\hline 7.7 & $\beta$-elemenone & 33.63 & N.D. \\
\hline 7.92 & Ascaridole & 11.02 & N.D. \\
\hline 7.99 & Cis-carvone oxide & 0.34 & N.D. \\
\hline 8.11 & D-carvone & 0.16 & N.D. \\
\hline 8.4 & Piperitenone oxide & 0.15 & N.D. \\
\hline 8.62 & Delta-elemene & 0.42 & N.D. \\
\hline 8.69 & 4-hydroxypiperitone & 0.11 & N.D. \\
\hline 8.85 & n-nonanylacetate & 0.4 & N.D. \\
\hline 9.03 & Thymol & 0.36 & 62.28 \\
\hline 9.39 & Ascaridole epoxide & N.D. & 0.39 \\
\hline 9.45 & Verbenone & 1.14 & N.D. \\
\hline 10.37 & Isojasmone & 31.57 & N.D. \\
\hline 10.77 & 6-allyl-o-cresol & N.D. & 4.16 \\
\hline 10.79 & Cinerolon & 1.23 & N.D. \\
\hline 11.07 & Caryophyllene & 5.23 & 1.81 \\
\hline 11.79 & 1,4-dimethoxy-2,5 dimethylbenzene & N.D. & 8.07 \\
\hline 11.88 & $\beta$-cedren & 0.13 & N.D. \\
\hline 11.99 & Linalyl isobutyrate & 0.21 & N.D. \\
\hline 12.24 & Germacrene D & 0.46 & N.D. \\
\hline 12.55 & C- elemene & 0.32 & N.D. \\
\hline 12.63 & p- tert- butylcatechol & N.D. & 1.32 \\
\hline 12.81 & $\beta$-bisabolen & 0.64 & N.D. \\
\hline 12.89 & Bicyclo(3,3,1)nonane-2,4-dione,3-(2,2-dimethyl propylielene)-methyl & 0.8 & N.D. \\
\hline 13.7 & O-isopropyl phenetole & N.D. & 0.81 \\
\hline 14.18 & Caryophyllene oxide & 0.37 & 0.64 \\
\hline 14.44 & Carotol & 0.22 & N.D. \\
\hline 14.8 & Cubenol & 0.11 & N.D. \\
\hline 15.3 & e-cadinol & 1.11 & N.D. \\
\hline 15.59 & Neryl butyrate & 0.28 & N.D. \\
\hline 15.65 & Neryl acetate & 0.13 & N.D. \\
\hline 18.22 & Cis-z- $\alpha$-bisabolene epoxide & N.D. & 1.91 \\
\hline 18.35 & 2,6-di-tert-butylhydroquinone & N.D. & 1.91 \\
\hline 18.85 & Hexahydro farnesylacetone & 0.16 & N.D. \\
\hline 21.12 & Manoyloxide & 0.15 & N.D. \\
\hline 24.47 & M-cymen-4-ol & N.D. & 0.79 \\
\hline 26.57 & 7-oxoAbieta-8,11,13-triene & N.D. & 1.46 \\
\hline 30.96 & Cirsimaritin & N.D. & 1.35 \\
\hline
\end{tabular}

*N.D. = not detected 
(Imelouane et al 2009, Mostafavi et al 2013). The variations in the content and compositional pattern of thyme and Stachys essential oils, however, may be due to several factors, including plants, growth stages, herb origin, environment and drying conditions (Sellami et al 2009, Baatour et al 2012).

\subsection{DPPH radical scavenging assay}

Using the DPPH radical scavenging assay, essential oils under investigation were subjected to antioxidant activity and compared with synthetic antioxidant (BHT) at 50, 100, 150 and $200 \mathrm{ppm}$, as well as, the findings are presented in Fig 1. It was revealed that activity was high at the level of $400 \mathrm{ppm}$ as the synthetic antioxidant BHT at $200 \mathrm{ppm}(77.29 \%)$. Whilst thyme essential oil exceeds the synthetic antioxidant BHT activity at levels 450 and $500 \mathrm{ppm}$. Stachys oil concentrations showed lower activity than synthetic antioxidant (BHT) up to $200 \mathrm{ppm}$ concentration. These findings indicate that the antioxidant activity increases with the increasing level of essential oil. These results confirmed the results obtained by Işcan et al (2012), Alsaraf et al (2020).

\subsection{Oxidative stability of sunflower oil and essential oils by Rancimat}

To evaluate substances that slow oxidation processes, fat and oil stability Rancimat measurement was used. Rancimat determines the induction period by measuring the rising volatile acidic by-products released at $100^{\circ} \mathrm{C}$ from oxidizing oil (Choe and Min 2009).

In the present work, the Rancimat test was used to assess the antioxidant activity of thyme and stachys essential oils applied to sunflower oil at different concentrations (200 and 500 $\mathrm{ppm})$ compared to BHT (200 ppm) and refined sunflower oil (without antioxidants) as mentioned in Fig 2.
As shown in Fig (2, the induction period for control sunflower oil (without additives) was 12.2 hour (hr.), which was increased to 13.84 $\mathrm{hr}$. in the same oil by adding $200 \mathrm{ppm}$ BHT. While the levels of thymeand stachysoils (200 ppm) gave the lower induction periods (as compared with the synthetic one but the induction period increased to $13.97 \mathrm{hr}$. in stachys oil and $14.2 \mathrm{hr}$. in thyme oil at $500 \mathrm{ppm}$.

Results are shown in Fig 2 suggested that BHT exhibits the highest antioxidant activity (1.13) compared to the sunflower oil samples under investigation at $200 \mathrm{ppm}$ but at $500 \mathrm{ppm}$ both thyme and stachys essential oils have higher antioxidant activity than BHT at 200 ppm. At the level of $500 \mathrm{ppm}$, Thyme and stachys essential oils deserve special attention because they were more effective than BHT at the level of $200 \mathrm{ppmin}$ delaying oxidation, and oxidative stability was directly proportional to the increase in the concentration of thyme and stachys essential oils. These results are in agreement with Hailemariam and Emire (2013).

\subsubsection{Acid value (AV) of mayonnaise}

As shown in Table 3, AVs of the control mayonnaise - samples changed from 0.274 in week 0 to 0.713 in week 5 during the storage period at $25^{\circ} \mathrm{C}$. A similar increasing trend versus storage period was also reported by Kishk and Elsheshetawy (2013). The rising pattern for AVs over time is attributable to mayonnaise low $\mathrm{pH}$ causing the iron bridges between iron and phosvitin to be broken and released. Hydrolytic and oxidative enzymes of an egg can be activated by Iron (Kishk and Elsheshetawy 2013, Honold et al 2016). Mayonnaise with additional essential stachys oil had the lowest $\mathrm{AV}$ at the end of the storage period (0.485), nevertheless, the discrepancy between test samples and samples of added antioxidants was not important. This shows that the addition of antioxidant in the spectrum of application does not affect $\mathrm{AV}$ s of mayonnaises. 


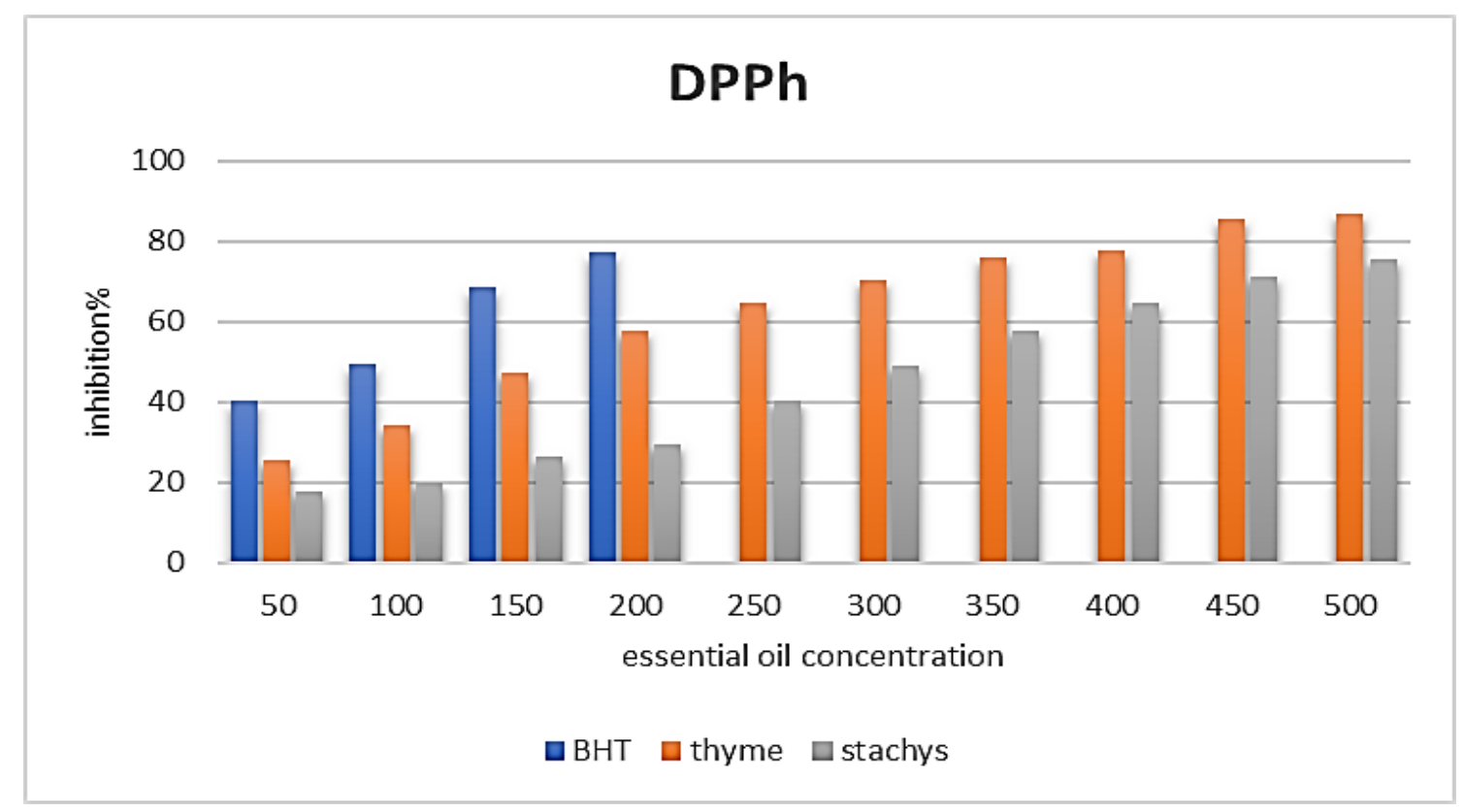

Fig 1 Antioxidant activity of Essential oil extracted by hydrodistillation using DPPH method (inhibition ratio \%)

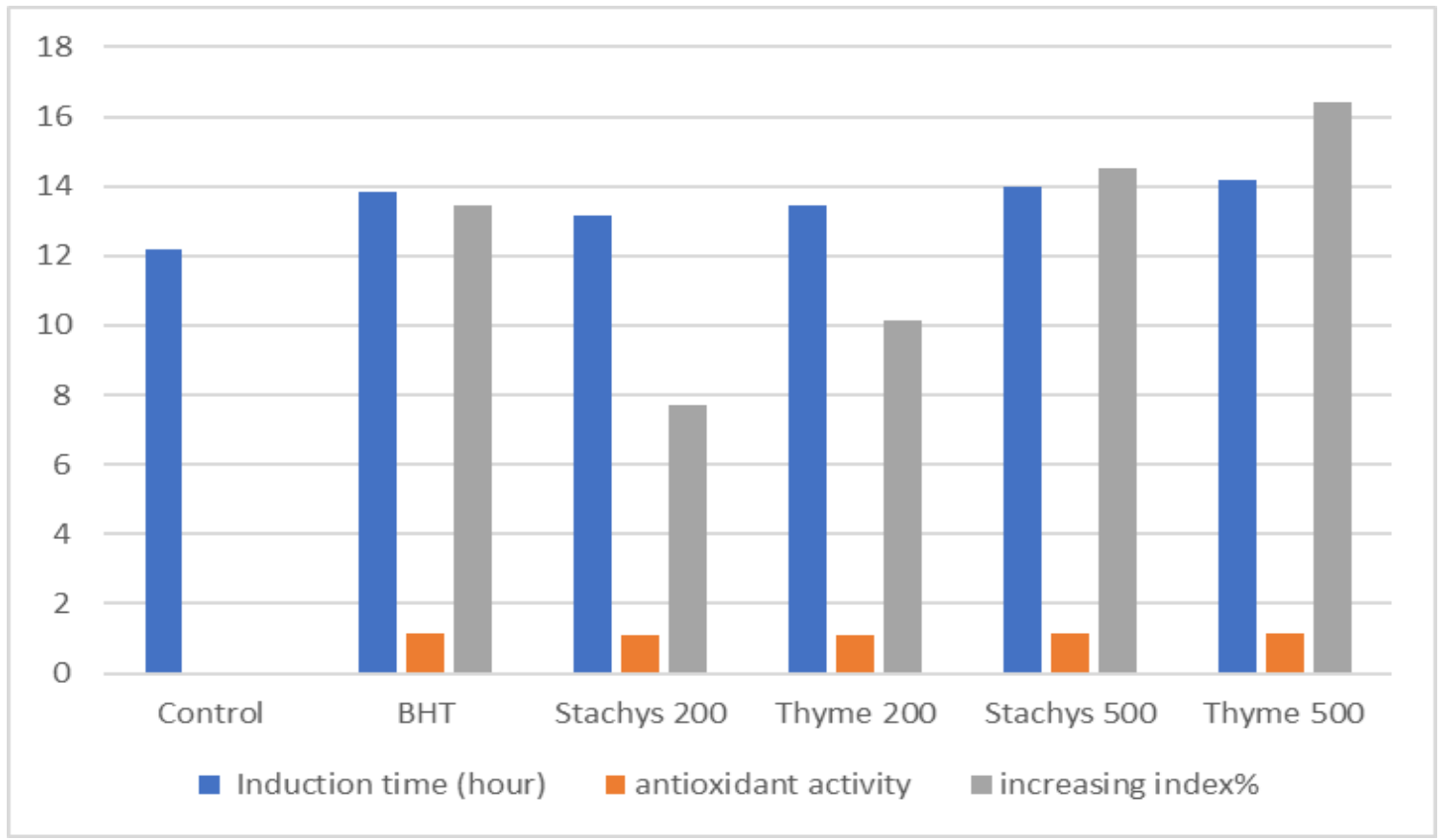

Fig 2. Effect of some essential oils on the oxidative stability of sunflower oil by Rancimat. 
Physico-Chemical Properties, Fractionation and Antioxidant Activity of Some Essential Oils Utilized in Mayonnaise Preparation and Storage

Table 3. The acid value of mayonnaise as affected by different levels of essential oils extracted by hydrodistillation during storage period at $25 \pm 2{ }^{\circ} \mathrm{C}$

\begin{tabular}{|c|c|c|c|c|c|c|}
\hline & \multicolumn{7}{|c|}{ Storage period (weeks) } \\
\cline { 2 - 6 } & $\mathbf{0}$ & $\mathbf{1}$ & $\mathbf{2}$ & $\mathbf{3}$ & $\mathbf{4}$ & $\mathbf{5}$ \\
\hline Control - & $0.274^{\mathrm{Af}}$ & $0.331^{\mathrm{Ae}}$ & $0.408^{\mathrm{Ad}}$ & $0.493^{\mathrm{Ac}}$ & $0.557^{\mathrm{Ab}}$ & $0.713^{\mathrm{Aa}}$ \\
\hline Control + & $0.268^{\mathrm{Ae}}$ & $0.268^{\mathrm{Be}}$ & $0.329^{\mathrm{Bd}}$ & $0.369^{\mathrm{Bc}}$ & $0.398^{\mathrm{Bb}}$ & $0.494^{\mathrm{Ba}}$ \\
\hline Thyme 200 & $0.26^{\mathrm{Af}}$ & $0.274^{\mathrm{Be}}$ & $0.337^{\mathrm{Bd}}$ & $0.377^{\mathrm{Bc}}$ & $0.407^{\mathrm{Bb}}$ & $0.505^{\mathrm{Ba}}$ \\
\hline Thyme 400 & $0.272^{\mathrm{Ae}}$ & $0.279^{\mathrm{Be}}$ & $0.343^{\mathrm{Bd}}$ & $0.384^{\mathrm{Bc}}$ & $0.415^{\mathrm{Bb}}$ & $0.515^{\mathrm{Ba}}$ \\
\hline Thyme 600 & $0.277^{\mathrm{Ae}}$ & $0.277^{\mathrm{Be}}$ & $0.34^{\mathrm{Bd}}$ & $0.381^{\mathrm{Bc}}$ & $0.412^{\mathrm{Bb}}$ & $0.51^{\mathrm{Ba}}$ \\
\hline Staychs 200 & $0.277^{\mathrm{Ae}}$ & $0.28^{\mathrm{Be}}$ & $0.344^{\mathrm{Bd}}$ & $0.386^{\mathrm{Bc}}$ & $0.417^{\mathrm{Bb}}$ & $0.517^{\mathrm{Ba}}$ \\
\hline Staychs 400 & $0.283^{\mathrm{Af}}$ & $0.275^{\mathrm{Be}}$ & $0.339^{\mathrm{Bd}}$ & $0.379^{\mathrm{Bc}}$ & $0.41^{\mathrm{Bb}}$ & $0.508^{\mathrm{Ba}}$ \\
\hline Staychs 600 & $0.277^{\mathrm{Af}}$ & $0.263^{\mathrm{Be}}$ & $0.323^{\mathrm{Bd}}$ & $0.362^{\mathrm{Bc}}$ & $0.391^{\mathrm{Bb}}$ & $0.485^{\mathrm{Ba}}$ \\
\hline
\end{tabular}

* Means with the same capital superscripts at the same column are not significant at $(\mathrm{p}<0.05)$

* Means with the same small superscripts at the same row are not significant at $(\mathrm{p}<0.05)$

Table 4. Thiobarbituric acid of mayonnaise as affected with different levels of essential oils extracted by hydrodistillation during storage period at $25 \pm 2{ }^{\circ} \mathrm{C}$

\begin{tabular}{|c|c|r|r|r|r|r|}
\hline & \multicolumn{7}{|c|}{ Storage period (weeks) } \\
\cline { 2 - 6 } & $\mathbf{0}$ & $\mathbf{1}$ & $\mathbf{2}$ & $\mathbf{3}$ & $\mathbf{4}$ & $\mathbf{5}$ \\
\hline Control - & $0.152^{\mathrm{Af}}$ & $0.213^{\mathrm{Ae}}$ & $0.383^{\mathrm{Ad}}$ & $0.575^{\mathrm{Ac}}$ & $0.711^{\mathrm{Ab}}$ & $0.895^{\mathrm{Aa}}$ \\
\hline Control + & $0.149^{\mathrm{Ae}}$ & $0.162^{\mathrm{Be}}$ & $0.178^{\mathrm{Bd}}$ & $0.267^{\mathrm{Bc}}$ & $0.33^{\mathrm{Bb}}$ & $0.416^{\mathrm{Ba}}$ \\
\hline Thyme 200 & $0.148^{\mathrm{Af}}$ & $0.176^{\mathrm{Be}}$ & $0.191^{\mathrm{Bd}}$ & $0.287^{\mathrm{Bc}}$ & $0.354^{\mathrm{Bb}}$ & $0.446^{\mathrm{Ba}}$ \\
\hline Thyme 400 & $0.151^{\mathrm{Af}}$ & $0.171^{\mathrm{Be}}$ & $0.187^{\mathrm{Bd}}$ & $0.281^{\mathrm{Bc}}$ & $0.347^{\mathrm{Bb}}$ & $0.437^{\mathrm{Ba}}$ \\
\hline Thyme 600 & $0.154^{\mathrm{Ae}}$ & $0.165^{\mathrm{Be}}$ & $0.183^{\mathrm{Bd}}$ & $0.275^{\mathrm{Bc}}$ & $0.339^{\mathrm{Bb}}$ & $0.427^{\mathrm{Ba}}$ \\
\hline Staychs 200 & $0.154^{\mathrm{Ae}}$ & $0.18^{\mathrm{Be}}$ & $0.203^{\mathrm{Bd}}$ & $0.305^{\mathrm{Bc}}$ & $0.377^{\mathrm{Bb}}$ & $0.475^{\mathrm{Ba}}$ \\
\hline Staychs 400 & $0.157^{\mathrm{Af}}$ & $0.177^{\mathrm{Be}}$ & $0.197^{\mathrm{Bd}}$ & $0.296^{\mathrm{Bc}}$ & $0.366^{\mathrm{Bb}}$ & $0.46^{\mathrm{Ba}}$ \\
\hline Staychs 600 & $0.154^{\mathrm{Af}}$ & $0.169^{\mathrm{Be}}$ & $0.186^{\mathrm{Bd}}$ & $0.279^{\mathrm{Bc}}$ & $0.345^{\mathrm{Bb}}$ & $0.434^{\mathrm{Ba}}$ \\
\hline
\end{tabular}

* Means with the same capital superscripts at the same column are not significant at $(\mathrm{p}<0.05)$

* Means with the same small superscripts at the same row are not significant at $(\mathrm{p}<0.05)$

\subsubsection{Thiobarbituric acid value (TBA) of mayonnaise}

Results showed the effect of various concentrations of thyme and stachys essential oil in comparison with the control sample (without any antioxidant). In the last week of antioxidant activity, the concentration of $600 \mathrm{ppm}$ for both essential oils was the best treatment and had a significant difference in comparison with synthetic antioxidant of $200 \mathrm{ppm}$ TBHQ Table 4. In short, all concentrations of thyme and stachys essential oils had an antioxidant activity similar to synthetic antioxidant of TBHQ at a concentration of $200 \mathrm{ppm}$ for inhibition of secondary products. These results are in agreement with Vahidyan et al (2012).

\section{Conclusion}

It is generally accepted that, unlike synthetic antioxidants, essential oils from thyme and stachys can be added in larger quantities to obtain optimal effects below their threshold level (addition of synthetic antioxidants is limited under food laws and regulations). As a result, with the addition of essential oil, which has antioxidant activity, the stability of refined oils has been increased. The essential oils of Thyme and Stachys could therefore be used in the food industry as a safe, effective and easily accessible source of the natural preservative ingredient. 


\section{References}

Ali B, Al-Wabel N, Shams S, Ahmad A, Khan S, Anwar F (2015) Essential oils used in aromatherapy: a systemic review. Asian Pac $J$ Trop Biomed 5, 601-611.

Alsaraf S, Hadi Z, Al-Lawati WM, Al-Lawati AA, Khan SA (2020) Chemical composition, in vitro antibacterial and antioxidant potential of Omani Thyme essential oil along with in silico studies of its major constituent, Journal of King Saud University - Science 32, 1021-1028.

Anwar F, Bhanger MI, Kazi TG (2003) Relationship between rancimat and active oxygen method values at varying temperatures for several oils and fats. J Amer Oil Chem Soc 80, 151-155.

AOCS (2005) Official Methods and Recommended Practices of AOCS. 5th Edition, The American Oil Chemists Society, Urbana

Baatour O, Tarchoune I, Mahmoud H, Nassr NW, Kaddour R, Hamdaou G, Ayachi MBN, Nasri BM, Lachaal M, Marzouk B (2012) Culture conditions and salt effects on essential oil composition of sweet marjoram (Origanum majorana) from Tunisia. Acta Pharm 62, 251261.

Basch E, Ulbricht C, Hammerness P, Blevins A, Sollars D (2004) Thyme (Thymus vulgaris L.), thymol. J Herb Pharmacother 4, 49-67.

Benjakul S, Visessanguan W, Thongkae C, Tanaka M (2003) Comparative study on physicochemical changes of muscle proteins from some tropical fish during frozen storage. $J$ Food Res Int 36, 787-795.

Bhavaniramya S, Vishnupriya S, Al-Aboody MS, Vijayakumar R, Baskaran D (2019) Role of essential oils in food safety: Antimicrobial and antioxidant applications, Grain \& Oil Science and Technology 2, 49-55.

Boskabady MH, Aslani MR, Kiani S (2006) Relaxant effect of Thymus vulgaris on guineapig tracheal chains and its possible mechanism(s). Phytother Res 20, 28-33.
Boukhatem M, Amine F, Kameli A, Saidi F, Walid K, Mohamed S (2014) Quality Assessment of the Essential Oil from Eucalyptus globulus Labill of Blida (Algeria) Origin. International Letters of Chemistry, Physics and Astronomy 36, 303-315.

Braga PC (2005) Thymol: Antibacterial, antifungal and antioxidant activities. Giornale Italiano di Ostetriciae Ginecologia 27, 267272.

Choe E, Min DB (2009) Mechanisms of Antioxidants in the Oxidation of Foods. Comprehensive Reviews in Food Science and Food Safety 8, 345- 358.

Constant S, Praisler M, Iordachescu G (2014) Identification of the main Physico-chemical properties influencing the quality of thyme (Satureja Hortensis). Journal of Engineering Studies and Research 20, 33-38.

Depree JA, Savage GP (2001) Physical and flavour stability of mayonnaise. Trends Food Sci Technol 112,157-163.

Frankel EN, Satue-Gracia T, Meyer AS, German JB (2002) Oxidative stability of fish and algae oils containing long-chain polyunsaturated fatty acids in bulk and oil in-water emulsions. J Agric Food Chem 50, 2094 - 2099.

Gedikoğlu A, Sökmen M, Çivit A (2019) Evaluation of Thymus vulgaris and Thymbra spicata essential oils and plant extracts for chemical composition, antioxidant, and antimicrobial properties. Food Sci Nutr 7, 1704-1714.

Goze I, Alim AS, Tepe AS, Sokmen M, Sevgi K, Tepe B (2009) Screening of the antioxidant activity of essential oil and various ex tracts of Origanum rotundifolium Boiss. from Turkey. $J$ Med Plants Res 3, 246-254.

Grigore A, Paraschiv I, Colceru-Mihul S, Bubueanu C, Draghici E, Ichim M (2010) Chemical composition and antioxidant activity of Thymus vulgaris $L$. volatile oil obtained by two different methods. Rom Biotech Lett 15, 54365443. 
Physico-Chemical Properties, Fractionation and Antioxidant Activity of Some Essential Oils Utilized in Mayonnaise Preparation and Storage

Guenther E (1961) The Essential Oil. Vol. 4, $4^{\text {th }}$ ed., D. Van Nostrandcompany, Inc. Princeton, New Jersey, Toronto, New York, London.

Gülçin I (2006) Antioxidant activity of caffeic acid (3,4-dihydroxycinnamic acid). Toxicol 217, 213-220.

Hailemariam G, Emire S (2013) Antioxidant Activity and Preservative Effect of Thyme (Thymus schimperi R.). British Journal of Applied Science and Technology 3, 1311-1326.

Holasova M, Fiedlerova V, Smrcinova H, Orsak M, Lachman J, Vavreinova S (2006)Buckwheat - the source of antioxidant activity in functional foods. Food Res Int 35, 207-211.

Honold PJ, Jacobsen C, Jónsdóttir R, Kristinsson HG, Hermund DB (2016) Potential seaweed-based food ingredients to inhibit lipid oxidation in fish-oil enriched mayonnaise. $\mathrm{Eu}$ ropean Food Research and Technology 242, 571-584.

Imelouane B, Hassan A, Wathelet J, Ankit M, Khedid K, El Bachiri A (2009) Chemical Composition and Antimicrobial Activity of Essential Oil of Thyme (Thymus vulgaris) from Eastern Morocco. International Journal of Agriculture and Biology 11, 205-208.

Iscan, G, Demirci, B, Demirci, F, Goger, F, Kirimer, N, Köse, Y, Baser, K, Husnu, C (2012) Antimicrobial and Antioxidant Activities of Stachys lavandulifolia subsp lavandulifolia Essential Oil and its Infusion. Natural Product Communications 7, 1241-1244.

Kishk Y, Elsheshetawy HE (2013) Effect of ginger powder on the mayonnaise oxidative stability, rheological measurements, and sensory characteristics. Annals of Agricultural Sciences 58, 213-220.

Kumar A (2014) Physico-chemical and natural products investigations of essential oil from the rhizomes of Kaempferia galanga L. Pelagia Research Library 5, 91-94.
Mostafavi H, Mousavi SH, Zalaghi A, Delsouzi R (2013) Chemical Composition of Essential Oil of Stachys byzantina from NorthWest Iran. Journal of Essential Oil Bearing Plants 16, 334-337.

Nadir A, Gamal M, Mohie M (2003). Tea Extracts as a natural antioxidant in Mayonnaise product. Egypt J of Nutrition 18, 53-82.

Nogala-Kalucka M, Korczak J, Dratwia M, Lampart-Szczapa E, Siger A, Buchowski M (2005) Changes in antioxidant activity and free radical scavenging potential of rosemary extract and tocopherols in isolated rapeseed oil triacylglycerols during accelerated tests. Food Chemistry 93, 227-235.

Parthiban KT, Selvan P, Paramathma M, Kanna SU, Kumar P, Subbulakshmi V, Vennila S (2011) Physico-chemical characterization of seed oil from Jatrophacurcas $L$. genetic resources. Journal of Economic and Natural Environment 3, 163-167.

Rota MC, Herrera A, Martínez RM, Sotomayor JA, Jordán MJ (2008) Antimicrobial activity and chemical composition of Thymus vulgaris, Thymus zygis and Thymus hyemalis essential oils. Food Control 19,681687.

Roy LG, Arabshahi-Delouee S, Urooj A (2010) Antioxidant efficacy of mulberry (Morus Indica $L$.) leaves extract and powder in edible oil. International Journal of Food Properties 13, 1-9.

Sellami IH, Maamouri E, Chahed T, Wannes WA, Kchouk ME, Marzouk B (2009) Effect of growth stage on the content and composition of the essential oil and phenolic fraction of sweet marjoram (Origanum majorana L.). Ind Crops Prod 30, 395-402.

Shaheen AM, Saleh IA, El-Kashoury ESA, Tawfik WA, Omar EA, Hegazy MEF, AbdelSattar E (2017) Microwave-assisted extraction as an alternative tool for extraction of Stachys aegyptiaca essential oil. Egypt Pharmaceut J $16,98-102$. 
Shahidi F (2005) Bailey's industrial oil and fat products. New Jersey: John Wiley \& Sons.

Shrestha S, Nyaupane DR, Yahara S, Rajbhandari M, Gewali MB (2013) Quality assessment of the essential oils from Artemisia gmelinii and Origanum majorana of Nepali origin. Scientic World 11,77-80.

Shrivastava G, Roger M, Wszelaki A, Panthee D, Chen F (2010) Plant volatiles-based insect pest management in organic farming. Crit Rev Plant Sci 29, 123-133.

Taghvaei M, Jafari SM(2015) Application and stability of natural antioxidants in edible oils in order to substitute synthetic additives. J Food Sci Technol 52, 1272-1282.

Vahidyan H, Sahari MA, Barzegar M, Naghdi Badi H (2012) Application of Zataria multiflora Boiss. and Saturejahortensis L. Essential
Oils as Two Natural Antioxidants in Mayonnaise Formulated with Linseed Oil. Journal of Medicinal Plants 11, 1-11.

Yağci S, Yagcı E, Gögüs F (2012) Antioxidative Effect of Thymbra spicata on Oxidative Stability of Palm and Corn Oils. International Journal of Food Properties - INT J FOOD PROP 15, 656-664.

Yanishlieva NV, Marinova EM (2001) Stabilisation of edible oils with natural antioxidants. European Journal of Lipid Science and Technology 103, 752-767.

Zugravu C, Pogurschi E, Pătraşcu D, Iacob P, Nicolae C (2017) Attitudes towards food additives: A pilot study. The Annals of the University Dunarea de Jos of Galati Fascicle VI Food Technology 41,1-12. 